Jurnal Abdidas Volume 1 Nomor 4 Tahun 2020 Halaman 215 - 221

JURNAL ABDIDAS

Community Development Service on Educational and Health Sciences

http://abdidas.org/index.php/abdidas

PAHLAWAN

\title{
Pelatihan Pembuatan Bakso Telur Landak Laut (Sea Urchin) sebagai Upaya Peningkatan Ekonomi dan Gizi Masyarakat Pesisir di Desa Kotajin, Gorontalo Utara
}

\author{
Mulis $^{1}$, Arafik Lamadi ${ }^{2}$, La Nane ${ }^{3}$ \\ Jurusan Budi Daya Perairan, Universitas Negeri Gorontalo, Gorontalo, Indonesia ${ }^{1,2}$ \\ Jurusan Manajemen Sumber Daya Perairan, Universitas Negeri Gorontalo, Gorontalo, Indonesia ${ }^{3}$ \\ E-mail: $\underline{\text { mulis@ung.ac.id }{ }^{1}} \underline{\text { arafik_lamadi@ung.ac.id }{ }^{2}} \underline{\text { lanane@ung.ac.id }}$
}

\begin{abstract}
Abstrak
Landak laut (sea urchin) merupakan salah satu produk sumber daya perikanan penting karena telurnya memiliki nilai ekonomis dan gizi yang baik untuk kesehatan. Desa Kotajin merupakan wilayah pesisir di Kabupaten Gorontalo Utara yang memiliki potensi yang cukup besar terhadap perikanan landak laut. Sayangnya, potensi tersebut belum dimanfaatkan dengan baik karena minimnya informasi dan pengetahuan tentang pengolahan telur landak laut menjadi penganan. Sejalan dengan itu, pemerintah lokal terus mengupayakan dan menghadirkan diversifikasi dari penganan baru yang bergizi dan bernilai ekonomis tinggi untuk mendorong peningkatan gizi dan perekonomian (pendapatan) masyarakat pesisir. Pengabdian ini dilaksanakan di Desa Kotajin pada tanggal 26-27 April 2019. Tujuan dari kegiatan ini adalah untuk memberikan pengetahuan kepada masyarakat Desa Kotajin tentang cara pembuatan bakso dari telur landak laut. Hasil dari kegiatan pelatihan ini adalah produk bakso dari telur landak laut yang siap untuk dikonsumsi atau dipasarkan kepada konsumen lokal.
\end{abstract}

Kata kunci: pelatihan, bakso, landak laut, gizi, ekonomi

\begin{abstract}
Sea urchin is one of the important fisheries resources products because its gonad has economic value and good nutrition for health. Desa Kotajin is a coastal area located at North Gorontalo Regency with a great potency for sea urchin fisheries products. Unfortunately, those urchins have not been exploited in well due to less information and knowledge on how to utilize sea urchin gonads for seafood. Moreover, the local government has been progressively supporting the new diversification of seafood from nutritional resources and high economic value to empower the increasing of nutrition intake and social-economic (income) in the coastal area. This work (community empowerment) was conducted at Desa Kotajin on April 26-27th 2019. The purpose of this work is to educate the coastal society at Desa Kotajin on how to create meatball from the gonad of sea urchin. The results of this work are meatballs of sea urchins that can be consumed and marketed to the local consumers.
\end{abstract}

Keywords: education, meatball, sea urchin, nutrition, economy

Copyright @ 2020 Mulis, Arafik Lamadi, La Nane

$\triangle$ Corresponding author:

Address : Jl. Jenderal Sudirman No.6, Kota Gorontalo 96128

Email : mulis@ung.ac.id

ISSN 2721- 9224 (Media Cetak)

Phone : 081328131572

ISSN 2721- 9216 (Media Online)

DOI: https://doi.org/10.31004/abdidas.v1i4.46 


\section{PENDAHULUAN}

Sejalan dengan pertambahan populasi penduduk Indonesia, dewasa ini, permintaan pangan dari produk perikanan seperti ikan kerapu, lobster dan udang semakin meningkat seiring dengan tingkat kesejahteraan masyarakat yang juga menuntut makanan bergizi (Irianto \& Soesilo, 2017). Namun demikian, kasus gizi buruk dan stunting akibat malnutrisi masih menjadi masalah besar di beberapa negara berkembang (Apriluana \& Fikawati, 2018; Dwijayanti \& Setiadi, 2020). Laporan terakhir dari Choliq et al. (2020) menyebutkan bahwa masalah stunting akibat kekurangan gizi masih menjadi masalah serius di Indonesia.

Kondisi ini tentu sangat ironis karena Indonesia merupakan salah satu negara yang sangat kaya akan hasil laut (Oktavia et al., 2012; Sukamto, 2017). Bahkan Negara Indonesia merupakan lumbung sumber protein dan gizi yang baik terutama dari sumber protein perikanan. Sayangnya, penciptaan nilai tambah terhadap produk perikanan masih relatif minim (Jamilah \& Mawardati, 2019). Terutama penganan diversifikasi seafood dari telur landak laut yang diolah sebagai pangan (Tupan \& Silaban, 2017). Sementara itu, di beberapa negara maju, telur landak laut telah lama dimanfaatkan untuk tujuan konsumsi baik dalam keadaan segar (Santos-Ferreira et al., 2020) maupun olahan (Nane, 2019b). Ragam olahan dari telur landak laut (sea urchin) yang umum dijumpai di Jepang adalah berupa produk kerupuk, kue, dan aneka camilan yang dikemas dengan cukup menarik.
Sementara itu, landak laut di Indonesia yang melimpah (Irianto et al., 2016), secara umum belum dimanfaatkan secara optimal sebagai sumber pangan (Baruadi \& Nane, 2020). Malahan, sebagian besar masyarakat pesisir di Indonesia masih menganggap landak laut sebagai biota laut beracun dan telurnya tidak layak untuk dikonsumsi (Nane et al., 2020). Selain itu, kehadiran landak laut yang melimpah di alam justru dipandang sebagai hama yang mengganggu (Ar et al., 2020). Akibat persepsi tersebut sumber daya landak laut semakin terpuruk dan terpinggirkan pengelolaannya. Akibatnya, landak laut semakin tidak dilirik sama sekali oleh masyarakat untuk dimanfaatkan.

Berbeda dengan Jepang yang sedari dulu sudah menjadi negara konsumen telur landak laut terbesar di dunia. Jepang bahkan telah memanfaatkan potensi telur landak lautnya secara optimal (Andrew et al., 2002; Baruadi \& Nane, 2020). Beragam produk penganan telur landak laut baik mentah atau olahan telah dipasarkan secara lokal di sejumlah pasar, swalayan, warung makan, dan restoran. Penganan mentah yang disajikan dalam kondisi segar umumnya berupa produk sushi. Sushi telur landak laut di jepang dikenal dengan nama uni (Kuwahara et al., 2009). Sushi tersebut biasanya disajikan dalam bentuk yang menarik yang atasnya dihiasi dengan telur landak laut segar yang memikat selera konsumen.

Di Indonesia, pemanfaatan landak laut yang tinggi banyak ditemukan di Kepulauan Wakatobi, Sulawesi Tengara (Nane \& Paramata, 2020) dan di Kepulauan Taliabu, Maluku Utara (Nane, 2020) Bahkan pemanfaatan landak laut di Wakatobi 
DOI: https://doi.org/10.31004/abdidas.v1i4.46

cukup tinggi dan telah mengakibatkan overfishing (Nane, 2019a). Hasil penelitian Nane (2019c) di Kepulauan Wakatobi menyebutkan bahwa ada 6 spesies landak laut yang telurnya telah dieksploitasi dan dikonsumsi secara lokal oleh masyarakat di Pulau Tomia. Spesies tersebut adalah Diadema setosum, Mespilia globus, Echinotrix calamaris, Tripneustes gratilla, Toxoneuptes pileolus, dan Echinometra sp. Sementara di Gorontalo, pemanfaatan telur landak laut belum dilakukan sama sekali.

Atas dasar persoalan tersebut, maka perlu dilakukan upaya pendidikan kepada masyarakat yang ada di Gorontalo khususnya di Desa Kotajin tentang pemanfaatan telur landak laut yang dapat dijadikan sebagai sumber pangan (nutrisi) dan upaya peningkatan ekonomi lokal melalui pelatihan pembuatan bakso dari telur landak laut (sea urchin).

\section{METODE}

Kegiatan pengabdian kepada masyarakat ini dilaksanakan pada 26-27April 2019 di Desa Kotajin, Kecamatan Atinggola, Kabupaten Gorontalo Utara. Adapun tahapan kegiatan ini pelatihan ini dilaksanakan dalam beberapa tahapan yaitu:

(1) Tahap Penyiapan Bahan

Telur landak laut (sea urchin) sebagai bahan utama pembuatan bakso telur landak laut diperoleh dari sumber daya pesisir di sekitar Desa Kotajin. Landak laut yang dipanen adalah landak laut yang telurnya telah berisi. Di alam landak laut ini hidupnya mengelompok dan umumnya matang secara bersamaan. Untuk mengetahui besaran ukuran telur siap panen, maka dilakukan pengambilan salah satu contoh sampel untuk dicek. Bila sudah berisi (Gambar 1), maka dilakukanlah pemanenan untuk dijadikan bahan baku dalam pembuatan bakso.

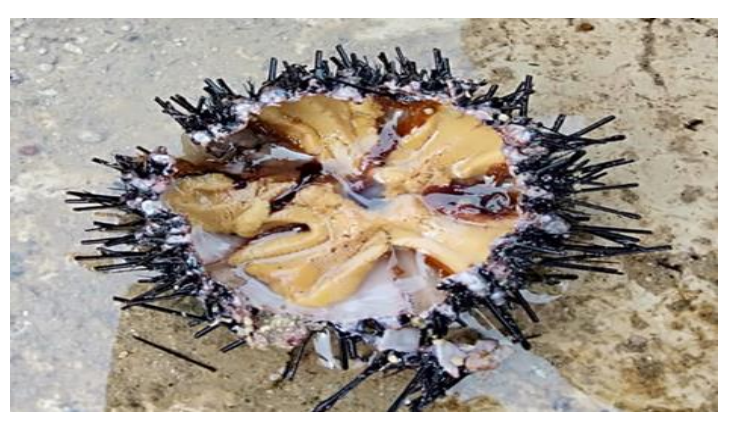

Gambar 1. Telur landak laut siap panen

\section{(2) Tahap Edukasi}

Setelah tahap pemanenan sumber daya landak laut di alam. Masyarakat juga diberikan materi penguatan (Gambar 2) tentang pengetahuan dan informasi tentang nutrisi landak laut. Metode penguatan pengetahuan ini dilakukan dalam bentuk kegiatan seminar oleh narasumber yang kompeten dibidang gizi perikanan dan produk landak laut. Dengan demikian, diharapkan masyarakat memiliki pengetahuan tentang landak laut dan kandungan gizi yang dimilikinya.

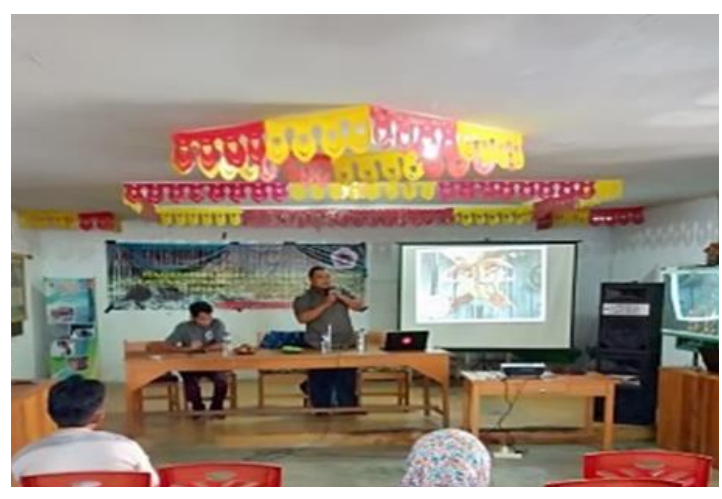

Gambar 2. Edukasi kandungan gizi landak laut di Desa Kotajin 
(3) Tahap Pembuatan Bakso

Tahap terakhir ini adalah tahap pembuatan bakso dari telur landak laut (Gambar 3).

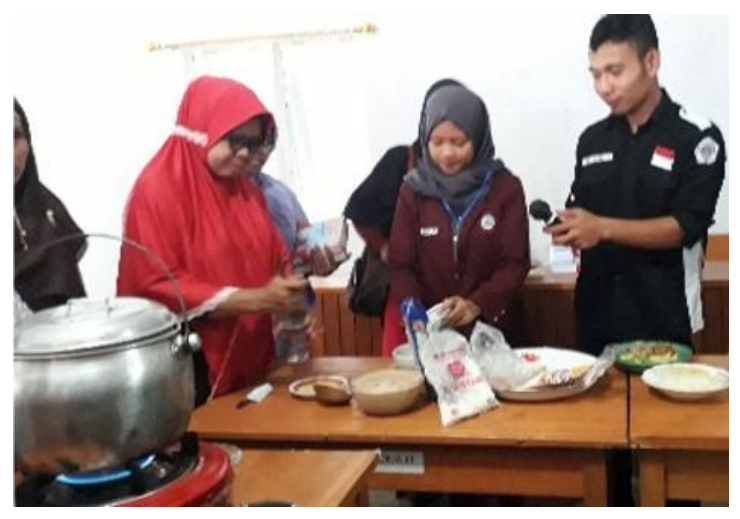

Gambar 3. Demo cara pembuatan bakso

Adapun alat dan bahan yang digunakan dalam pembuatan bakso telur landak laut dapat dilihat pada Tabel 1.

Tabel 1. Alat dan Bahan

\begin{tabular}{cl}
\hline No & Alat dan Bahan \\
\hline 1 & Landak laut (50 ekor) \\
2 & Bawang putih (secukupnya) \\
3 & Bawang merah (secukupnya) \\
4 & Garam \\
5 & Tepung tapioka (1 kg) \\
6 & Telur ayam (2 butir) \\
7 & Penyedap rasa (masako) \\
8 & Garam dan Merica (secukupnya) \\
9 & Air bersih (secukupnya) \\
10 & Tirisan \\
11 & Kompor gas \\
12 & Panci kukus \\
13 & Pengoyak telur \\
14 & Mangkok adonan \\
\hline
\end{tabular}

Sementara itu, Langkah-langkah pembuatan bakso telur landak laut adalah sebagai berikut:

1) Rebus telur landak laut yang sudah dipisahkan dari cangkang. Lalu, haluskan dengan pengoyak telur. Campur telur landak laut yang sudah halus dengan bawang putih, bawang merah, telur, garam, merica, penyedap rasa sampai benar-benar tercampur.

2) Tuangkan adonan tersebut ke sebuah wadah lalu masukan tepung tapioka sambil diadukaduk sampai semua bahan tercampur. Setelah itu tambahkan dengan sedikit air.

3) Lalu, siapkan panci dan rebus air kaldu sampai mendidih

4) Bentuk adonan bakso sampai membentuk bulatan.

5) Ambil adonan bakso lalu masukan dalam air kaldu yang sudah direbus di panci.

6) Rebus bakso dengan api sedang sampai bakso dari telur landak laut matang dan mengambang ke permukaan air.

7) Setelah matang, angkat lalu tiriskan.

8) Bakso siap disajikan.

\section{HASIL DAN PEMBAHASAN}

Pendekatan diversifikasi pangan baru melalui olahan bakso dari telur landak laut cukup efektif. Dengan demikian, masyarakat yang tadinya menganggap landak laut sebagai hewan beracun dapat diajak dengan mudah untuk turut terlibat dalam proses belajar tentang cara membuat bakso dari telur landak laut. Pendekatan diversifikasi pangan pada pelatihan ini digunakan sebagai trik dalam merangsang minat masyarakat setempat, khususnya kaum ibu yang selama ini berdedikasi menjadi dapur produksi rumah tangga.

Penulis percaya, bila ibu-ibu telah belajar dan menerima produk telur landak laut sebagai produk perikanan yang layak konsumsi melalui olahan bakso yang enak. Maka perlahan-lahan masyarakat 
akan berupaya mencoba memanfaatkan telur landak laut terutama dalam keadaan segar (fresh) seperti yang dilakukan oleh masyarakat di Jepang dan di Kepulauan Wakatobi yang telah mengonsumsi telur landak laut secara mentah yang kaya akan nutrisi.

Dengan demikian, asupan nutrisi rumah tangga paling tidak semakin beragam bukan saja karena dengan kehadiran menu bakso telur landak laut (Gambar 4). Tapi juga dengan pola konsumsi telur landak laut secara segar atau dalam bentuk olahan lainnya. Sehingga masyarakat mendapatkan sumber-sumber protein baru.

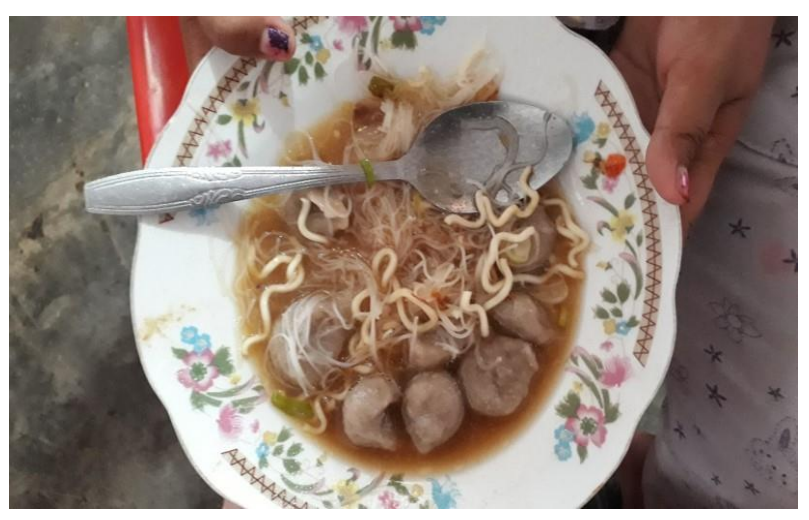

Gambar 4. Bakso telur landak laut

\section{Penerimaan masyarakat Desa Kotajin} terhadap penganan bakso dari telur landak laut merupakan suatu sinyal posistif. Artinya, bila masyarakat dapat menerima landak laut sebagai penganan yang layak untuk dikonsumsi dan dimanfaatkan, maka pengabdian ini cukup berhasil mengubah paradigma masyarakat setempat. Sebab ukuran keberhasilan kegiatan pengabdian ini adalah masyarakat dapat menerima landak laut sebagai penganan dan memanfaatkannya sebagai penganan bakso.
Karena, selama ini masyarakat Desa Kotajin menganggap landak laut sebagai hewan yang beracun. Karena itu, masyarakat sangat antusias mendengar bahwa telur landak laut dapat dikonsumsi dan diversifikasi menjadi penganan baru berupa bakso. Tujuannya diversifikasi telur landak laut menjadi bakso adalah untuk meningkatkan asupan gizi masyarakat setempat yang sebelumnya belum pernah mengonsumsi telur landak laut. Dengan demikian. Masyarakat setempat dapat menciptakan potensi usaha baru untuk meningkatkan pendapatan melalui penjualan bakso dari telur landak laut.

Adapun catatan penting, mengapa sebelumnya telur landak laut di Desa Kotajin belum dimanfaatkan sebagai penganan oleh masyarakat setempat adalah karena minimnya informasi soal pemanfaatan telut landak laut. Termasuk minimnya sosialisasi dan kegiatan pelatihan dari pemerintah setempat tentang pemanfaatan telur landak laut. Namun dengan adanya pelatihan pembuatan bakso yang dilaksanakan oleh tim penulis. Landak laut kini mulai dikenal sebagai salah satu biota laut yang telurnya bergizi tinggi, dan dapat dikonsumsi dan mulai dimanfaatkan oleh masyarakat setempat.

\section{SIMPULAN}

Minimnya pemanfaatan landak laut di Desa Kotajin, Gorontalo utamanya disebabkan oleh dua faktor utama yaitu: (1) minimnya informasi tentang pemanfaatan landak laut, dan (2) minimnya pengetahuan tentang cara pengolahan landak laut. Akan tetapi dengan pelatihan ini, masyarakat mulai mendapatkan informasi tentang landak laut yang 
selama ini dianggap beracun dan juga mendapatkan penguatan tentang diversifikasi pangan berupa olahan telur landak laut menjadi bakso yang dapat dikonsumsi untuk meningkatkan gizi dan pendapatan masyarakat setempat.

\section{UCAPAN TERIMA KASIH}

Penulis mengucapkan banyak terima kasih kepada LPPM Universitas Negeri Gorontalo atas segala bantuan dan dukungannya sehingga kegiatan ini dapat terlaksana dengan baik. Tak lupa pula rasa terima kasih kami sampaikan kepada Perangkat Desa Kotajin yang telah banyak membantu dan memfasilitasi kami selama berada di lokasi.

\section{DAFTAR PUSTAKA}

Andrew, N. L., Agatsuma, Y., Ballesteros, E., Bazhin, A. G., Creaser, E. P., Barnes, D. K. A., ..., \& Einarsson, S. (2002). Status and management of world sea urchin fisheries. Oceanography and Marine Biology, 40(40), 343-425. https://eprints.utas.edu.au/1255

Apriluana, G., \& Fikawati, S. (2018). Analisis Faktor-Faktor Risiko terhadap Kejadian Stunting pada Balita (0-59 Bulan) di Negara Berkembang dan Asia Tenggara. Media Penelitian Dan Pengembangan Kesehatan, 28(4), 247-256. https://doi.org/10.22435/mpk.v28i4.472

Ar, S., Karnan, K., Japa, L., Merta, I. W., \& Mertha, I. G. (2020). Meningkatkan Kualitas Produksi Rumput Laut Melalui Pelatihan tentang Sistem Pengelolaan Budidaya Secara Terpadu di Gili Gede Lombok Barat NTB. Jurnal Pengabdian Magister Pendidikan IPA, 2(1), 66-70.

https://doi.org/10.29303/jpmpi.v2i1.356

Baruadi, A. S. R., \& Nane, L. (2020). Edukasi Pemanfaatan Bulu-Babi (Sea Urchin) Melalui Budi Daya Keramba Jaring Apung. Jurdimas
Royal, 3(2), 169-174. https://doi.org/10.33330/jurdimas.v3i2.666

Choliq, I., Nasrullah, D., \& Mundakir, M. (2020). Pencegahan stunting di Medokan Semampir Surabaya melalui modifikasi makanan pada anak. Humanism: Jurnal Pengabdian Masyarakat, 1(1), 31-40. http://journal.umsurabaya.ac.id/index.php/HMN/article/downl oad/4544/2678

Dwijayanti, F., \& Setiadi, H. (2020). Pentingnya Kesehatan Masyarakat, Edukasi dan Pemberdayaan Perempuan untuk Mengurangi Stunting di Negara Berkembang. Prosiding Seminar Nasional Kesehata, 16-25. http://ejurnal.stikesrespatitsm.ac.id/index.php/semnas/article/view/246

Irianto, A., Jahidin, J., \& Sudarajat, H. W. (2016). Kelimpahan Bulu Babi (Echinoidea) di Intertidal Perairan Pulau Liwutongkidi Kecamatan Siompu Kabupaten Buton Selatan. Jurnal Ampibi, 1(2), 27-30. http://ojs.uho.ac.id/index.php/ampibi/article/v iew/5034

Irianto, H. E., \& Soesilo, I. (2017). Dukungan teknologi penyediaan produk perikanan. Seminar Nasional Hari Pangan Sedunia, 120.http://old.litbang.pertanian.go.id/special/H PS/dukungan_tek_perikanan.pdf

Jamilah, J., \& Mawardati, M. (2019). Hubungan Tingkat Kemiskinan dengan Pemanfaatan Sumberdaya Perikanan Tangkap pada Kawasan Minapolitan. Jurnal Ekonomi Pertanian Dan Agribisnis, 3(2), 336-347. https://doi.org/10.21776/ub.jepa.2019.003.02 .10

Kuwahara, R., Hatate, H., Yuki, T., Murata, H., Tanaka, R., \& Hama, Y. (2009). Antioxidant property of polyhydroxylated naphthoquinone pigments from shells of purple sea urchin Anthocidaris crassispina. LWT - Food Science and Technology, 42(7), 1296-1300. https://doi.org/10.1016/j.lwt.2009.02.020

Nane, L. (2019a). Impact of overfishing on density and test-diameter size of the sea urchin Tripneustes gratilla at Wakatobi Archipelago, 
south-eastern Sulawesi, Indonesia. BioRxiv, 727271.

https://www.biorxiv.org/content/10.1101/727 $271 \mathrm{v} 1$

Nane, L. (2019b). Sea Urchin Sustainability Studies Based on Dimension Biology, Ecology and Technology at Around of Tolandono Island and Sawa Island at Wakatobi Conservation Area. https://doi.org/10.31230/osf.io/4whz6

Nane, L. (2019c). Studi Keberlanjutan Perikanan Landak Laut Berdasarkan Dimensi Biologi, Ekologi Dan Teknologi Di Sekitar Pulau Tolandono Dan Pulausawa Kawasan Konservasi Wakatobi [Skripsi, Universitas Hasanuddin]. https://marxiv.org/9zdvr/

Nane, L., Baruadi, A. S. R., \& Mardin, H. (2020). Density of the blue-black urchin Echinotrix diadema (Linnaeus, 1758) in Tomini Bay, Indonesia. Tomini Journal of Aquatic Science, $1(1)$, $16-21$. https://doi.org/10.37905/tjas.v1i1.5939

Nane, L. (2020,). Pemanfaatan Telur Landak Laut Diadema setosum di Pulau Taliabu, Maluku Utara, Indonesia. Open Science for Fisheries, $1(1)$, $1-5$. https://doi.org/10.31219/osf.io/kmtuv

Nane, L., \& Paramata, A. R. (2020). Impact of Overfishing on Density and Test-Diameter Size of the Sea Urchin Tripneustes gratilla at Wakatobi Archipelago, South-Eastern Sulawesi, Indonesia. ILMU KELAUTAN: Indonesian Journal of Marine Sciences, 25(2), 53-56.

https://doi.org/10.14710/ik.ijms.25.2.53-56

Oktavia, D. A., Mangunwidjaja, D., Wibowo, S., Sunarti, T. C., \& Rahayuningsih, M. (2012). Pengolahan Limbah Cair Perikanan Menggunakan Konsorsium mikroba Indigenous Proteolitik dan Lipolitik. Agrointek: Jurnal Teknologi Industri Pertanian, 6(2), 65-71.

Santos-Ferreira, N., Mesquita, J. R., Rivadulla, E., Inácio, Â. S., Nascimento, M. S. J., Romalde, J., \& Martins da Costa, P. (2020). Norovirus contamination of sea urchins (Paracentrotus lividus): Potential food risk for consumers. Food Control, 111, 107041. https://doi.org/10.1016/j.foodcont.2019.1070 41

Sukamto, S. (2017). Pengelolaan Potensi Laut Indonesia dalam Spirit Ekonomi Islam (Studi Terhadap Eksplorasi Potensi Hasil Laut Indonesia). MALIA: Jurnal Ekonomi Islam, 9(1), 35-61. https://doi.org/https://doi.org/10.35891/ml.v9 i1.881

Tupan, J., \& Silaban, B. B. (2017). Karakteristik Fisik-Kimia Bulu Babi Diadema setosum dari Beberapa Perairan Pulau Ambon. Triton: Jurnal Manajemen Sumberdaya Perairan, $13(2)$, $71-78$ https://ojs3.unpatti.ac.id/index.php/triton/arti cle/view/786 